\section{Sanja Kojić Mladenov} Muzej savremene umetnosti Vojvodine Novi Sad, Srbija sanja.kojic@msuv.org
DOI: https://doi.org/10.18485/slovenika.2018.4.1.3

UDK: 7.071.1 Srebotnjak-Prišić L. 7.038.53:77

\title{
Lidija Srebotnjak Prišić - profesionalni identitet intermedijske umetnice i profesorke $^{1}$
}

\section{Sažetak}

U oblasti medijske umetničke prakse u Srbiji značajna je uloga žena, naročito $\mathrm{u}$ domenu video i digitalne umetnosti, dok su, međutim, njihova vidljivost i valorizacija u stručnoj i široj javnosti još uvek izazov za nova istraživanja. U radu Lidija Srebotnjak Prišić - profesionalni identitet intermedijske umetnice i profesorke istaknuta je značajna edukativna i umetnička aktivnost Lidije Srebotnjak Prišić, intermedijalne umetnice i profesorke novih likovnih medija slovenačkog porekla. Potrebno je izdvojiti slojevitost i fluidnost profesionalnog identiteta ove vizuelne umetnice i ukazati na njega, analizirati njen profesorski rad na Akademiji umetnosti u Novom Sadu i paralelni razvoj sopstvene umetničke prakse, te pronaći mogućnost za veću vidljivost njenog doprinosa $u$ javnosti. Uočljivo je da je Lidiji Srebotnjak Prišić profesionalni identitet najistaknutiji, dok ostalim identitetima umetnica pristupa kao promenljivim kategorijama. Ona posebno pridaje važnost prenošenju znanja i formiranju novih kadrova u cilju održavanja kontinuiteta $\mathrm{u}$ neposrednoj praksi, uvođenju intermedijske prakse $\mathrm{u}$ umetnosti, te uspostavljanju kontakta sa slovenačkom umetničkom scenom. Paralelne profesionalne aktivnosti daju osnova za analizu identiteta umetnice i profesorke, te njegovog pojavljivanja i vrednovanja u javnosti.

Ključne reči: fluidni identitet, rodne studije, savremena vizuelna umetnost, umetnica, medijska umetnička praksa

\footnotetext{
${ }^{1}$ Rad je deo doktorske teze Sanje Kojić Mladenov: Diskursi o rodu u umetnosti: konstrukcija profesionalnog identiteta umetnica koje se bave novim medijima u Vojvodini krajem 20. i početkom 21. veka, odbranjene na ACIMSI Centru za rodne studije UNS (07. 09. 2018).
} 
Prelazak graničnih polja različitih naučnih i umetničkih disciplina oduvek je privlačio pažnju svojom inovativnošću i smelošću ka iskoraku, ali su takva iskustva istovremeno bila predmet kritike i osporavanja, kao i ignorisanja. Počeci novih medija u umetnosti proizveli su zbog svog eksperimentalnog pristupa kritiku kako tadašnje umetničke scene tako i naučne zajednice. Novi mediji u umetnosti ukrstili su jezik likovne umetnosti sa znanjima iz oblasti prirodnih nauka, sa rezultatima naučnih istraživanja i mogućnostima savremenih tehnologija, te proizveli intermedijsku praksu koja je značajno izmenila dotadašnje poimanje umetnosti. Medijska umetnost je jedan od aktuelnih umetničkih procesa u međunarodnom kulturnom prostoru, uz značajno učešće i umetnika i umetnica iz Srbije, čije mesto u istoriji umetnosti i kulturnoj javnosti još uvek nije dovoljno istraženo i vrednovano. Postavlja se pitanje mesta i uloge žene u ovim procesima, te njihovog doprinosa, koji ne bi smeo biti ignorisan ili zapostavljen. Novije istraživanje profesionalng identiteta umetnica koje se bave novim medijima ukazalo je na značaj edukativne i umetničke aktivnosti Lidije Srebotnjak Prišić, intermedijalne umetnice i profesorke novih likovnih medija, slovenačkog porekla, čija biografija ukazuje na kontinuirano održavanje kontakta sa savremenom slovenačkom umetničkom scenom.

Naime, posle iskustava stečenih na studijama Istorije umetnosti na Filozofskom fakultetu u Beogradu, te završenih osnovnih studija slikarstva na Akademiji umetnosti u Novom Sadu, Lidija Srebotnjak Prišić odlazi na magistarske studije (tzv. slikarsku specijalku) na Akademiji umetnosti u Ljubljani (1985-1986). U to vreme, koleginice i kolege su joj bili Marjetica Potrč na skulpturi, Dunja Zupančić, Alenka Pirman, te Andrej Savski iz grupe Irvin, i drugi koji su se bavili inovativnim stvaralaštvom. U to vreme, važnu ulogu u razvoju alternativne umetničke scene Ljubljane imaju ŠKUC, Kersnikova 4 (K4), programi u Cankarjevom domu i kinoteci, koji su uz izložbe činili inspirativno profesionalno okruženje, značajno za razvoj stavova o umetnosti i početke njene umetničke prakse. ${ }^{2}$

U tom periodu se Lidija Srebotnjak Prišić počinje baviti i likovnom kritikom i književnim prevodom sa slovenačkog na srpski jezik. Ona piše tekstove o umetnosti, uglavnom likovnu kritiku i prikaze aktuelnih umetničkih događanja, kao što je bila velika izložba kineske umetnosti u Zagrebu, i tome sl. „U Ljubljani sam, na podsticaj

\footnotetext{
${ }^{2}$ Period studiranja u Ljubljani bio je prožet saradnjom i komunikacijom s Dejanom Poznanovićem, slavistom i prevodiocem sa slovenačkog jezika, koji joj je umnogome pomogao u upoznavanju sa literaturom potrebnom za teorijski rad (Hlebnjikov (Khlebnikov), Srečko Kosovel, Taras Kermauner i dr.).
} 
Zorana Đerića, tada je uređivao Glas omladina, uradila nekoliko prikaza - razgovore sa urednicima Tribune, potom razgovor sa grupom Juni, sa Lev Menaševim. Rad Ideologija i ikonologija boja: crvene, bele $i$ crne pisan za profesora Tomaža Brejca, na predmetu Teorija umetnosti, objavljen je u ljubljanskom stručnom časopisu Likovnie bese-

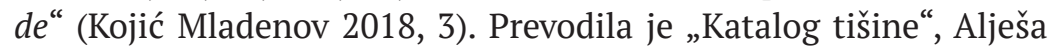
Debeljaka, i dela Andreja Blatnika za časopis Polja iz Novog Sada. Uz početnu podršku Bogdanke i Dejana Poznanovića, zastupnika nove umetničke prakse iz Novog Sada, koji su održavali stalni kontakt sa ljubljanskom avangardnom kulturnom scenom, Lidija Srebotnjak Prišić takođe čini sponu ljubljanske i novosadske umetničke scene, sa značajnim postignućima i u novijem periodu.

Već na početku umetničkih istraživanja ona sagledava umetnost kao zajedničko delovanje autora / autorki koji / koje pripadaju različitim oblastima, razvija otvorenost ka interdisciplinarnim istraživanjima. „To je ujedno postavilo moj lični rad u intermedijalni kontekst, kroz tekst, fotografiju, sliku i kolažni postupak, baziran na iskustvima koja su proizašla i iz teorijskih istraživanja“" (Kojić Mladenov 2018, 3). Stavovi o umetnosti Lidije Srebotnjak Prišić bili su bliski aktuelnim umetničkim tokovima onoga perioda $u$ kome su u umetnosti sve važnija postajala intermedijalna istraživanja u okviru kojih su se granična područja tradicionalnih likovnih disciplina izlagala međusobnim uticajima, formalnim i idejnim preplitanjima, a pod uticajem različitih društvenih, naučnih i tehnoloških praksi. Težnja umetnica / umetnika je bila usmerena ka eksperimentima kojima su rušile / rušili granice istorijskih medija, kao što su npr. slikarstvo ili skulptura, te ka uvođenju elektronskih medija, performansa i digitalne umetnosti. Rezultat su bile specifične vrste intervencija unutar značenja i metoda, analize politike reprezentacije i kritike konvencionalnog shvatanja umetnosti.

Inovacije na polju medijske prakse bile su prisutne i u Novom Sadu, gde se umetnica vraća kako bi započela svoju profesorsku karijeru, najpre u okviru intermedijskih eksperimenata profesorke Bogdanke Poznanović ${ }^{3}$, kao njena asistentkinja, a zatim kao redovna profesorka - jedan od osnivača Katedre za nove likovne medije 2002. godine, prve sa takvim usmerenjem u Srbiji. „Za Akademiju umetnosti u Novom Sadu značajno je rano otvaranje ka novim tehnologijama i njihovo uključivanje u studijski proces. Video je po prvi put uveden $u$ program nastave na Akademiji umetnosti $u$ Novom

\footnotetext{
${ }^{3}$ Ona osniva Vizuelni studio za intermedijalna istraživanja na Akademiji umetnosti u Novom Sadu 1979. godine, prvi takve vrste u nekadašnjoj Jugoslaviji.
} 
Sadu, dugo je to bilo i jedino mesto, u odnosu na umetničke akademije sa prostora bivše Jugoslavije, gde je ta praksa bila moguća.“ (Kojić Mladenov 2018, 191). Istraživanja studenata / studentkinja u formi videa, performansa ili ambijentalnih instalacija bila su prožeta međusobnom saradnjom i povezivanjem likovnog odseka sa dramskim i muzičkim odsekom, čime se postizala interdisciplinarnost značajna i za savremena zbivanja u umetničkoj praksi.

Takođe, Lidija Srebotnjak Prišić prenosi iskustvo sa Akademije u Ljubljani, gde je provela postdiplomske studije sredinom 80 -ih godina prošlog veka, u vreme kada su se uvodili novi mediji. „Ljubljanska Akademija je počela da se otvara ka novim tehnologijama, 1985. ili 1986. godine. Srečo Dragan je počeo da predaje nešto kao nove medije na Odseku za dizajn. Andrej Jemec je tada bio šef katedre, znam da su polako uvodili nove medije i da su im jako bile važne veze koje su Bogdanka i Dejan imali sa Nušom i Srečom Dragan.“ (Kojić Mladenov 2018, 209). Izuzev Ljubljane, koja je prva posle Novog Sada pokazala otvorenost ka novomedijskoj umetnosti, ostali jugoslovenski umetnički centri doživeli su promene tek u drugoj polovini 90-ih godina 20 . veka ili početkom 21 . veka, a u nekima još nije došlo do napretka, ili se pak proces polako odvija, što ukazuje na inventivnost profesorskog kadra koji je u to vreme radio na akademijama u Novom Sadu i Ljubljani.

Tokom 90-ih godina 20. veka, sa razvojem medijske umetnosti, čemu doprinosi i pojava personalnih računara i interneta, te dolaskom nove generacije studenata / studentkinja upućenih u rad sa digitalnim medijima „bilo je neophodno stvaranje nove katedre gde je studijski proces podrazumevao upravo rad sa novim tehnologijama“ (Kojić Mladenov, 198), što je za logičan sled imalo otvaranje posebnog usmerenja posvećenog novim likovnim medijima. Informacije o napretku koji je postignut uvođenjem novih medija u edukativni proces u Novom Sadu bile su poznate i u jugoslovenskom regionu, o čemu svedoče brojne prezentacije i projekcije studentskih radova $\mathrm{u}$ inostranstvu.

Lidija Srebotnjak Prišić aktivno učestvuje u podizanju novog kadra u nauci, pogotovo na Novim likovnim medijima, gde danas rade studenti i studentkinje kojima je predavala. Inovirala je postojeće i učestvovala u stvaranju novih predmeta, čak i usmerenja. Istraživanja uspeha u nauci se uglavnom bave brojem objavljenih naučnih radova i izlaganja na konferencijama / izložbama, napredovanjima u zvanjima i funkcijama, a manje se bave „nevidljivim“ aktivnostima, onima na koja se teško mogu primeniti kvantitativna istraživanja. U 
pitanju su podaci koji najčešće ne čine ustaljene biografske forme, kao što je značaj saradnje, komunikacije, podrške i pomoći mladima. Kao i u slučaju slabijeg vrednovanja učešća žena u naučnim projektima, jer u njima ima najviše žena (Savić 2015), tako se ni izgradnja mreže i novih kadrova ne afirmiše kao izuzetan doprinos u nauci.

Paralelno sa svojim profesorskim aktivnostima, Lidija Srebotnjak Prišić se istovremeno bavi sopstvenom umetničkom praksom. Kontinuirano je, kroz svoje stvaralaštvo usmerena na privatno-javne relacije, na ispitivanje pozicija žene i ženskog senzibiliteta u umetnosti, kao i složenog odnosa unutar samih likovnih medija, koje nadograđuje i razvija kroz ispitivanje pozicije klasičnih i novih medija, kao i njihovog dijaloga. Okrenuta je korišćenju slajda, fotografije i videa, te prostornih foto i video instalacija, ali istovremeno istražuje u klasičnim medijima, kao što su crtež, slika i digitalna grafika, uz korišćenje fotografije kao stalno prisutne reference.

Jedno od prvih fotografskih istraživanja Lidije Srebotnjak Prišić odlikuje saradnja sa koleginicom Biljanom Golubović na realizaciji serije foto-performansa ${ }^{4}$ (1984). Koncept rada čini vizuelno iskustvo fotografski zabeleženog razgovora dve prijateljice, njihove priče i gestikulacije, što ukazuje na zainteresovanost autorke, već u njenim ranim istraživanjima, na uvođenje ženskog odnosa i komunikacije u javni prostor. Istupanje ženskog identiteta, iako uvek suptilno, ostaje trajna karakteristika radova Lidije Srebotnjak Prišić. Takođe, neopterećenošću materijalnom formom rada, njegovom krajnjom realizacijom koja je bila efemerna, autorka ukazuje na još neke odlike umetničkog dela koje su njoj važne, a to je isticanje procesa rada i eksperimentisanja sa postupkom, te važnost situiranja rada u novi prostor, kako bi se postigao kratkotrajni doživljaj, a ne materijalnost i trajnost dela, što je bilo u suprotnosti sa dominatnom umetničkom scenom i njenom institucionalnom prepoznatljivošću.

U svom prvom video-radu Ekran (1984), ${ }^{5}$ postupak medija slike prenela je u postupak video-performansa. Rani video Lidije Srebotnjak Prišić postavlja u prvi plan ruke autorke, koje su uposlene stalnim aktivnostima svojevrsnog igranja sa likovnim materijalima (gužvanje papira, razlivanje boje...). Umetničkim eksperimentom uspostavljene su relacije između tela autorke, njegove performativ-

\footnotetext{
${ }^{4}$ Rad je izlagan prvi put u Foto-kino klubu Branko Bajić (1984), zajedno sa Predragom Šiđaninom i Jozefom Klaćikom, zatim u Srećnoj galeriji u Beogradu, kao i na izložbi Jugoslovenska fotografija u Americi.

${ }^{5}$ Rad je prikazan u okviru predstavljanja studentskih radova Akademije umetnosti $\mathrm{u}$ inostranstvu.
} 
nosti i likovnosti, ali kroz nagoveštaj prisustva žene u umetničkom radu. I u ovom slučaju, video-zapis je bio segment krajnje realizacije rada. Postavljala bi ga uvek kao instalaciju, vodeći računa o njegovoj situaciji u prostoru, potencirajući mogućnost kreiranja dinamične slike u ambijentu i njegove komunikacije i suodnosa sa drugim likovnim medijima i sa posmatračem. Efemernost materijala je prisutha i u ovom njenom radu.

U narednoj seriji radova, Lidija Srebotnjak Prišić upotrebljava elemente iz svog privatnog / porodičnog arhiva. Ona uglavnom koristi fotografsku građu kao početni medij za dalje intervencije $i$ istraživanja, a zatim ga procesom reciklaže transponuje $u$ druge medije, i tek nakon tog procesa iznosi rad u javnost. „Fenomen fotografije kao aktuelnog medija savremenog umetničkog izražavanja kod Lidije Srebotnjak Prišić prati se kontinuirano kroz višegodišnji studijski rad u različitim aspektima fotografske prakse: od tradicionalne fotografije, video art-a, slajd projekcije, kompjuterske fotografije, digitalne štampe, foto instalacija i foto ambijenata" (Dobrić 2005, 2).

Stare porodične fotografije uglavnom izlaže kao foto i video instalacije. U instalaciji Označavanje $(1996)^{6}$, polazište je bila fotografija, kompjuterski obrađena. „Iskoristila sam fotografiju školskog razreda iz porodičnog albuma, na kojoj su ispisani brojevi na svakom detetu (utisnuti $u$ fotografiju), rukopis verovatno fotografa radi identifikacije dece. Fotografija je iz 1936. godine, nastala u Beogradu. Pojavile su se 3 gotovo iste fotografije sa nekim minimalnim pomeranjima. Istraživala sam samu fotografiju, skenirala je, a zatim u segmentima prebacila na slajd film“ (Kojić Mladenov 2018, 115). Slajdovi su projektovani na pausima, koji su zbog svoje transparentnosti uticali na ambijentalni doživljaj postavke, otvorene za posmatrača. Na suptilan način, kroz brojčano označavanje dece na školskoj fotografiji, upućivano je na prisutnu dehumanizaciju i obezvređivanje ljudskog života. Umetnički rad je delovao potresno zbog aktuelnog društvenog konteksta, ratnih stradanja i migracija na prostoru nekadašnje Jugoslavije.

Autorka procesualno istražuje odnos privatno-javnog prostora, kroz „propitivanje“ pozicije intimnog i emotivnog kao društveno i umetnički vrednog. U više svojih radova, kao što su Indukovane slike

\footnotetext{
${ }^{6}$ Izlagano u Galeriji (Muzeju) savremene umetnosti u Novom Sadu (1996); kustos izložbe je bio Miloš Arsić i na izložbi Regionalno univerzalno u Pančevu (1997), a autorka izložbe je bila Svetlana Mladenov.
} 


\section{S. Kojić Mladenov \\ Lidija Srebotnjak Prišić - profesionalni...}

(1997), Intermeco ${ }^{7}$ (1998, 1999), Izdaleka - izbliza ${ }^{8}$ (2005), Intencija prisustva (2016) i drugi, L. Srebotnjak Prišić ukazuje na bliskost dva stanja - stvarnosti i prošlosti, na isečak iz intimne situacije, koji naglašava autorkino prisustvo - to sam ja, a sa druge strane, bavi se i složenim odnosima unutar samih likovnih medija, gde klasične medijske pozicije nadograđuje i razvija tehnološkim pristupima. Fotografije su svedenog kolorita, segmenti njenog intimnog sveta. One su reference stvarnih situacija, predstavljenih bez pokreta, zaustavljenih, zadržanih u metafizičkoj mirnoći da „propituju“ odnos stvarnog i imaginarnog, prošlosti i sadašnjosti. Analizirajući dihotomiju njihovih odnosa i situacija, Lidija Srebotnjak Prišić ne želi da poremeti postignuti balans koji među njima postoji, niti da nekome od njih ukaže prednost, kao što ne želi ni da utiče na posmatrača i određuje čitljivost umetničkog dela. Sopstveno delo ostavlja u promenljivom odnosu prema različitim prostorima i situacijama, $\mathrm{u}$ određenom smislu nedovršeno i istovremeno otvoreno za različita tumačenja i pristupe, $\mathrm{u}$ čemu se ogleda i potreba za neautoritarnim senzibilitetom, koji sopstveni „arhiv“ fotografija dekonstruiše u komunikaciji sa javnošću.

Sam pojam arhiva kao akumuliranih znanja koje proizvode različiti tipovi institucija, kao i druge organizovane strukture društva ili pojedinci / pojedinke, nailazio je kroz istoriju, takođe i pod uticajem feminizma, na potrebu za dekonstrukcijom svojih značenja i praksi. „Iako su arhivi 'primarni izvori' koji nose obeležje neutralnosti, već sama metodologija akumuliranja predstavlja dizajn koji angažuje društvene, političke i tehnološke moći. Epistemološka uloga arhiva, kao i simbolički kapital arhiva, srazmerni su i njihovoj lociranosti u sistemu produkcije moći“ (Kojić Mladenov, Nikolić 2016, 72). Pojedine umetnice se bave (re)interpretacijom određenih arhivskih (javnih i privatnih) celina i njihovim diskurzivnim talozima, (de) konstrukcijom pamćenja i projekcijom novih (mikro) istorija, kao i procesom beleženja i kreiranja novih arhivskih celina koje afirmišu ženski doprinos društvu, kulturi i umetnosti.

\footnotetext{
${ }^{7}$ Rad Intermeco je izlagan na izložbi Između lika i odraza u MSUB (1998) i na izložbi Kritičari su izabrali, u Kulturnom centru Beograda, autora Nikole Šujice (1999).

${ }^{8}$ Rad Izdaleka - izbliza je prvi put izlagan u Kulturnom centru Beograda (2005), zatim u Galeriji Zlatno oko u Novom Sadu, na izložbi Grad - umetnička pozornica, autorke Svetlane Mladenov, na izložbi Situacije- instalacije u Vojvodini (2013), autorke Sanje Kojić Mladenov, u Muzeju savremene umetnosti Vojvodine (MSUV), na izložbi Konflikti, provokacije, relacije, izazovi, strepnje, energije, odlučnosti: umetnost u proširenom polju, pogled na umetničku situaciju: Vojvodina 1997/2014. (2015) u MSUV-u, Novi Sad, i na izložbi Akvizicije: otkupi i pokloni 2012-2015. Rad je otkupljen od strane MSUV-a (2013).
} 


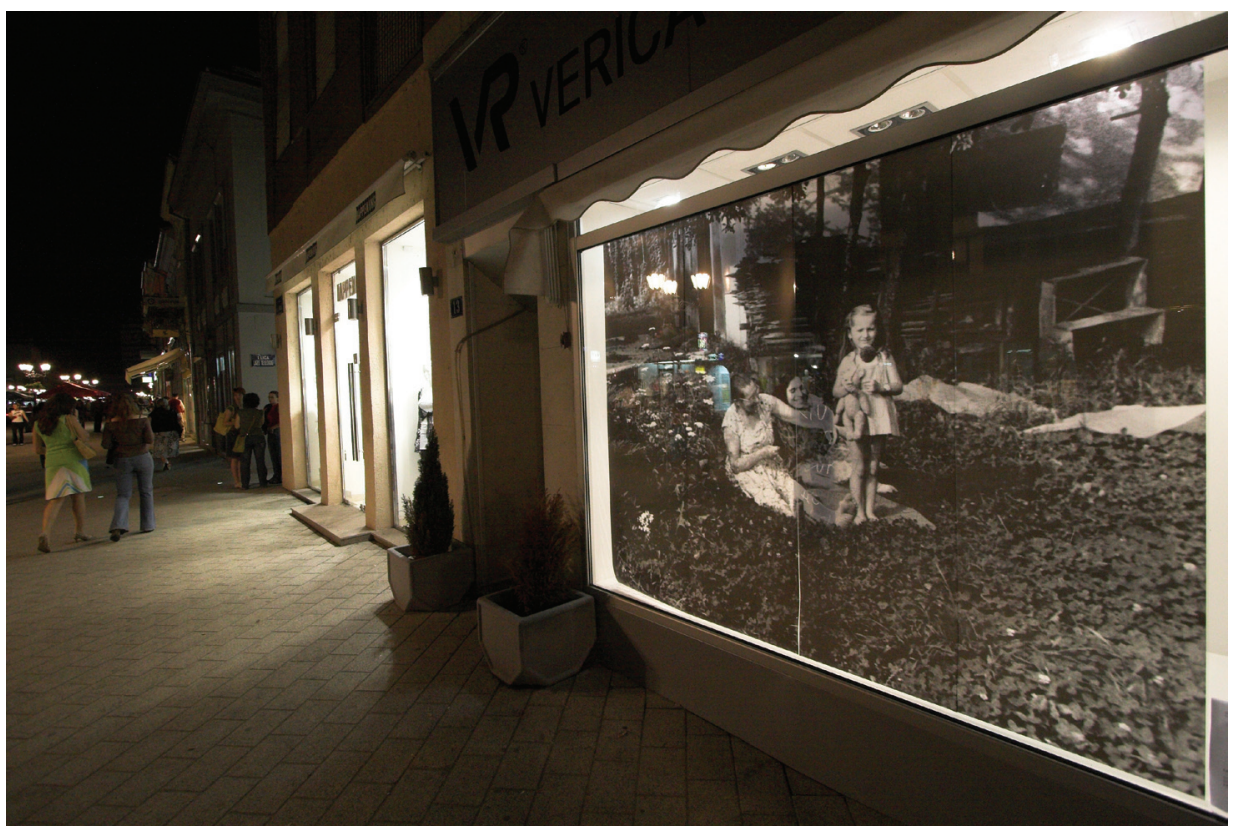

Izdaleka - izbliza

Među njima je i Lidija Srebotnjak Prišić, čiji je koncept rada često usmeren na istupanje ženskog identiteta, uz stavljanje u prvi plan fotografije žena ili porodice, uvek u određenom međuodnosu. „Fotografije koje izaberem imaju neki punktum unutar kompozicije koji me privuče. Ničim nisu bile specifične. Često su u pitanju nepoznate osobe. Kad je pronađem, kao fotografija sa dve žene koje sede u prostoru nekog pejzaža ${ }^{9}$ ili velika porodična fotografija $u$ prostoru $^{10}$, koja je krajnje lična, kroz raščitavanje one otvaraju čitav sklop suodnosa ponavljanja ili stereotipa, prisutno kao nešto efemerno, a opet nataloženo unutar individualnog, ličnog ili kolektivnog iskustva" (Kojić Mladenov 2018, 116). Prikaz iz sopstvene arhive intimnog prostora autorka ne iznosi eksplicitno u javnost, već mu daje univerzalnu prepoznatljivost i vrednost, kao što mu ostavlja i otvorenost za analizu i zaključivanje. Svaka od njenih fotografija čini se kao bliska i poznata posmatraču dela, kao segment porodične svakodnevice, a sa druge strane - kao prikaz ženske istorije i ženske generacijske povezanosti.

Istovremeno sa samostalnom umetničkom praksom, Lidija Srebotnjak Prišić je učestvovala u grupnim projektima, u okviru kojih je

\footnotetext{
${ }^{9}$ Rad Indukovane slike.

${ }^{10} \mathrm{Rad}$ Izdaleka - izbliza.
} 


\section{S. Kojić Mladenov \\ Lidija Srebotnjak Prišić - profesionalni...}

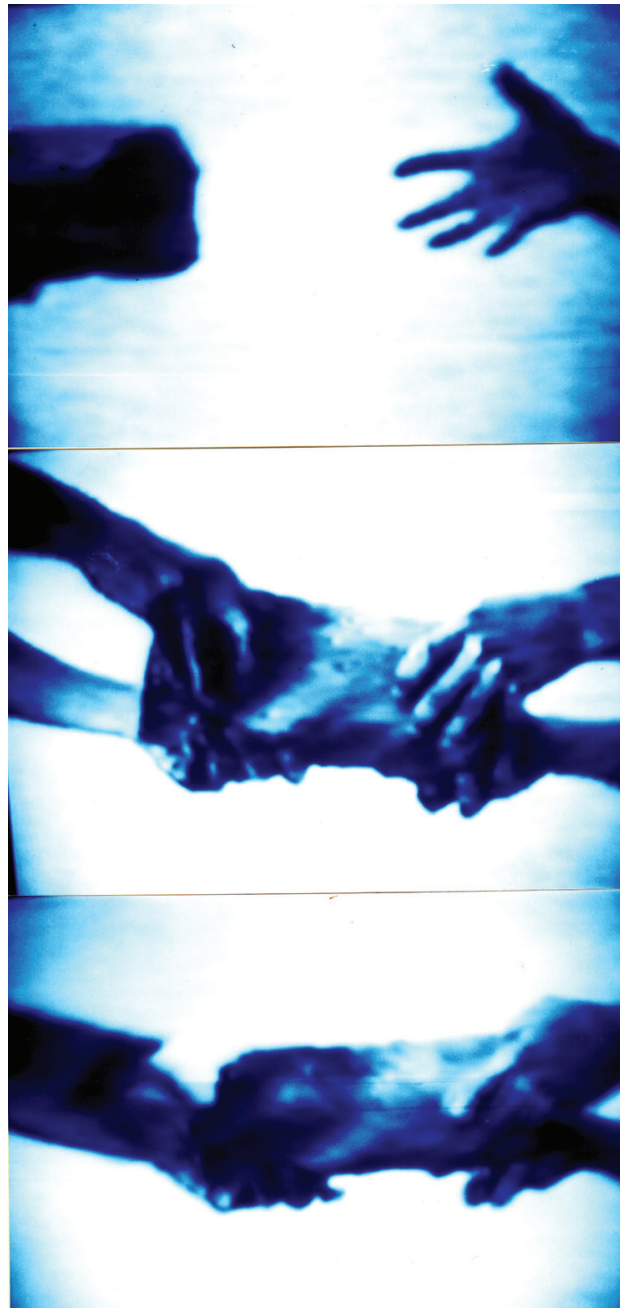

Viribus Unitis

ispitivala kontekst prostora i mogućnosti umetničkih intervencija. Značajan in situ rad - Viribus Unitis (1992) realizovala je zajedno sa kolegama Zoranom Pantelićem i Miroslavom Šilićem, i sa koleginicom Bojanom Petrić na specifičnom mestu - na Tvrđavi u Novom Sadu, za koju su namenski obrazovali celokupni multimedijski koncept. „Mislim da smo uradili sjajan rad, koji svojom realizacijom upućuje na ono što će se na ovim prostorima odvijati tek ovih godina, pravi sajt specifik rad realizovan savremenom tehnologijom. Projekcijama smo obuhvatili čitav prostor Petrovaradinske tvrđave“ (Kojić Mladenov 2018, 266). U pitanju je bio kompleksni audio-vizuelni događaj, izveden samo jedne večeri, u sklopu obeležavanja tristote godišnjice nastanka Tvrđave. Idejnu podlogu čini istraživanje o društveno-istorijskom, mitološkom i arhitektonskom kontekstu specifičnog mesta realizacije rada, realizovanom kroz više audio i video instalacija.

Umetnička intervencija $\mathrm{u}$ javnom prostoru, koju je odlikovalo i kolektivno stvaranje, jeste određena vrsta umetničkog „manevra“, odnosno procesa izmeštanja umetničkog rada iz konvencijalnih izložbenih prostora, kao što su to galerije i muzeji, u netipičan, „neumetnički“ okvir. Ovakve in situ radove odlikuje efemerni karakter i fizička nestalnost, kao i kritika dominatne kulturne politike i moći institucija kulture. Alternativni prostor zahtevao je participativnost posetilaca, koji su, koristeći pripremljenu mapu rada, morali da se kreću od jedne do druge tačke, kako bi propratili svaki segment, te mogli da sagledaju celinu koncepta. Inovativnost je događaju pružio i susret sa novomedijskom kulturom, umetničkim radovima realizovanim kroz video-projekcije, što je omogućilo posmatračima novi doživljaj uobičajenog prostora. Koncept koji je bio pripremljen za specifičnu lokaciju nije više ponovljen, a ume- 
tnički rad nije publikovan u svom konačnom obliku, što otežava saznanje o njemu čak i među usko stručnom domaćom javnošću. Takva situacija utiče na nevidljivost doprinosa umetnika / umetnica i na smanjenu mogućnost analize i istraživanja novomedijske umetničke prakse.

Navedeni podaci ukazuju na to da je Lidija Srebotnjak Prišić svojim profesionalnim radom paralelno usmerena na proces obrazovanja i sopstveni umetničko-istraživački rad. Pokušava da balansira između ova dva pola svoga poziva i načina bavljenja medijskom umetnošću. Aktivnosti vezane za edukaciju i umetničko stvaralaštvo u stalnom su preplitanju. „Mislim da mi je kvalitetan rad sa studentima jednako tako važan kao i moj lični rad. Katedra za nove medije je dominantno mesto mog profesionalnog angažovanja. Stvorili smo kreativan i inovativan prostor za istraživanje savremene umetničke prakse i novih medija. Ima puno zainteresovanih, kreativnih mladih ljudi koje je važno da motivišeš. Ne treba ništa više od toga. Motivacija za njihov lični rad, ne i uticaj na njihov rad“ (Kojić Mladenov 2018, 216). Ona pridaje važnost prenošenju znanja, uvođenju i inoviranju predmeta, formiranju novih kadrova, timskom radu i umrežavanju, što je vidljivo u njenoj aktivnosti na Akademiji umetnosti u Novom Sadu. Zainteresovana je naročito za inovacije u polju pristupa novim likovnim medijima i metodama rada, kako u procesu edukacije tako i svom umetničkom stvaralaštvu, koje se kreće $u$ polju intermedijske umetničke prakse. O njenom profesionalnom radu ima pisanih tekstova, ali se oni nalaze $u$ različitim izvorima, na mnogim jezicima i na raznim geografskim prostorima. Njen doprinos nije dovoljno vidljiv $\mathrm{u}$ javnom kulturnom prostoru, te se čini važnim da se uspostavi sistem čuvanja ne samo radova nego i arhiviranja dokumentacije o umetnicama u okviru novih medija, budući da su podaci koji su rasuti po različitim izvorima i privatnim kolekcijama slabo dostupni javnosti, i da se na taj način o ovakvim profesionalnim aktivnostima počne više govoriti u javnom medijskom prostoru, $u$ institucijama kulture i obrazovnim institucijama.

\section{Literatura}

Dobrić, Gordana. 2005.,Ponešto o tajnama fotografija Lidije Prišić Srebotnjak“. U Lidija Prišić Srebotnjak Izdaleka - izbliza, digitalne fotografije [katalog izložbe], 2-3. Beograd : Kulturni centar. 


\section{S. Kojić Mladenov \\ Lidija Srebotnjak Prišić - profesionalni...}

Kojić Mladenov, Sanja i Gordana Nikolić. 2016. „Archive + Power. Performing the Archive in Art“. U Performing the Museum, ur. Dušan Grlja i Aleksandra Sekulić, 72-77. Novi Sad : MSUV.

Kojić Mladenov, Sanja. 2018. Diskursi o rodu u umetnosti: konstrukcija profesionalnog identiteta umetnica koje se bave novim medijima $u$ Vojvodini krajem 20. i početkom 21. veka. Doktorska disertacija. Univerzitet u Novom Sadu - ACIMSI - Centar za rodne studije.

Savić, Svenka. 2015. Profesorke Univerziteta u Novom Sadu: životne priče. Novi Sad: Ženske studije i istraživanja i Futura publikacije.

Sanja Kojić Mladenov

Muzej sodobne umetnosti Vojvodine

Novi Sad, Srbija

sanja.kojic@msuv.org

\section{LIDIJA SREBOTNJAK PRIŠIĆ - PROFESIONALNA IDENTITETA INTERMEDIJSKE UMETNICE IN PROFESORICE}

Na področju medijske umetniške prakse v Srbiji je vloga žensk pomembna, še posebej v polju video in digitalne umetnosti, hkrati pa sta njihova vidljivost in volarizacija znotraj strokovne in širše javnosti še vedno izziv za nove raziskave. V delu Lidija Srebotnjak Prišić - profesionalna identiteta intermedijske umetnice in profesorice je poudarjena pomembna izobraževalna in umetniška aktivnost Lidije Srebotnjak Prišić, intermedialne umetnice in profesorice novih likovnih medijev slovenskega izvora. Posebej se je treba posvetiti večplastnosti in fluidnosti profesionalne identitete te vizualne umetnice in jo osvetliti, analizirati njeno profesorsko delo na Akademiji umetnosti v Novem Sadu in paralelni razvoj lastne umetniške prakse ter odkriti možnosti za večjo javno vidljivost njenega doprinosa. Očitno je, da je najbolj poudarjena profesionalna identiteta Lidije Srebotnjak Prišić, medtem ko k ostalim identitetam umetnica pristopa kot $\mathrm{k}$ spremenljivim kategorijam. Posebno pomembnost prepoznava $\mathrm{v}$ prenašanju znanja in formiranju novih kadrov, s ciljem ohranjanja kontinuitete $\mathrm{v}$ neposredni praksi, $\mathrm{v}$ uvajanju intermedijske prakse $\mathrm{v}$ umetnost in vzpostavljanju kontaktov s slovensko umetniško sceno. Paralelne profesionalne aktivnosti nudijo osnovo za analizo identitete umetnice in profesorice, njenega pojavljanja in vrednotenja v javnosti.

Ključne besede: fluidna identiteta, študije spola, sodobna vizualna umetnost, umetnica, medijska umetniška praksa 
Sanja Kojić Mladenov

The Museum of Contemporary Art Vojvodina

Novi Sad, Serbia

sanja.kojic@msuv.org

\section{LIDIJA SREBOTNJAK PRIŠIĆ - THE PROFESSIONAL IDENTITY OF AN INTERMEDIA ARTIST AND PROFESSOR}

In media art practice in Serbia, women have a prominent role, especially in the domain of video and digital arts. At the same time, their visibility and standing in the eyes of the professional and general public remain a challenge for further research. The study Lidija Srebotnjak Prišić - The Professional Identity of an Intermedia Artist and Professor highlights the significant educational and artistic activity of Lidija Srebotnjak Prišić, an intermedia artist of Slovenian origin and a university professor of new artistic media. It is necessary to show and to highlight the multidimensional character and fluidity of the visual artist's professional identity and analyze her professorial activities at the Academy of Arts in Novi Sad and the parallel development of her independent artistic practice. It is also important to ensure a greater public visibility of her contribution to art. It is apparent that the professional identity of Lidija Srebotnjak Prišić is the most prominent, while she approaches other identities as variable categories. She pays special attention to the transfer of knowledge and the development of new professional staff, seeking to ensure continuity in practice, introduce intermedia practice in art, and establish contacts with the Slovenian art scene. Her parallel professional activities provide a basis for analyzing the artist and professor's identity, and his manifestations and evaluation in the public.

Keywords: fluid identity, gender studies, modern visual art, woman artist, media art practice 